\author{
$n^{\circ}$ 2012-27 \\ Employment Policies, \\ Hiring Practices and Firm \\ Performance \\ S. BLASCO ${ }^{1}$ \\ B. PERTOLD-GEBICKA ${ }^{2}$
}

November 2012

Les documents de travail ne reflètent pas la position du CREST et n'engagent que leurs auteurs. Working papers do not reflect the position of CREST but only the views of the authors.

\footnotetext{
1 Gains-University of Le Mans, CREST and IZA.

2 Aarhus University and Charles University in Prague.
} 


\title{
Employment Policies, Hiring Practices and Firm Performance
}

\author{
Sylvie Blasco* \\ Barbara Pertold-Gebicka ${ }^{\dagger}$ \\ Gains, University of Le Mans, Crest and IZA \\ Aarhus University and Charles University in Prague
}

November $2012 \ddagger$

\begin{abstract}
In this paper we investigate how active labour market policy programmes affect firms' hiring strategies and, eventually, firms' performance. We focus on counseling and monitoring which may reduce search costs for employers, but which may have ambiguous effect on the employeremployee matching quality and thus on firms' performance. Using a large scale experiment which was conducted in Denmark in 2005-2006 and induced a greater provision of activation, we find that small firms hiring in the districts where the social experiment was conducted changed their hiring practices in favor of unemployed workers and experienced greater turnover than the other firms. Treated firms also experienced no change or a marginal reduction in value added and total factor productivity during the first years after the experiment. These results are consistent with the idea that monitoring creates compulsion effects which counteract the possible improvement in the matching process expected from job search assistance.
\end{abstract}

Keywords: active labour market programmes; counseling and monitoring; hiring decisions; firms performance

JEL Classification numbers: C21, J63, J68

\footnotetext{
*Email: sylvie.blasco@univ-lemans.fr. Address: University of Le Mans, Avenue O. Messiaen, 72085 Le Mans Cedex 9, France.

${ }^{\dagger}$ Email: bpertold@econ.au.dk. Address: Department of Economics and Business, Aarhus University, Fuglsangs Alle 4, 8210 Aarhus V, Denmark.

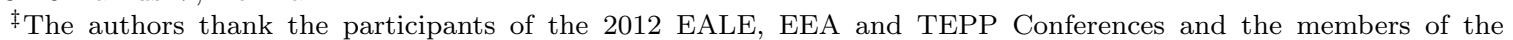
Departments of Economics and Business of Aarhus University, University of Le Mans and Crest for useful suggestions. We are grateful to the FSE Research Unit "An Economic Analysis of the Impact of the Scandinavian Welfare State and Flexicurity Policies on Danish Firms" for financing this research and to Statistics Denmark for providing the data.
} 


\section{Introduction}

In most European countries active labour market policy programmes (ALMPs) have been largely developed over the past decade. The rich literature evaluating these programmes focuses on outcomes related to individuals participating in the interventions (see the meta-analysis by Kluve (2010) or Card et al. (2010)). Recently, the general equilibrium effects of ALMPs have been evaluated (Crépon et al. (2011); Ferracci et al. (2010); Gautier et al. (2012)), but with a focus on nonparticipants indirectly affected by these programmes, and there is still limited evidence on how ALMPs may affect firms' behaviours and outcomes (Gautier et al. (2012); Lechner et al. (2012)). In this paper, we offer to fill the existing gap in the literature by providing an empirical analysis of how two important components of ALMPs, namely job search assistance dedicated to the unemployed workers and monitoring and sanctions, affect firms' hiring decisions and performance. By investigating firm-level outcomes, we aim at getting a more comprehensive evaluation of the costs and benefits of ALMPs.

Labour market institutions play a crucial role in hiring and firing strategies of firms. Employers face a number of challenges to fill a vacancy. First, frictions on the labour market make hiring more difficult. Second, in case of imperfect screening technology, the ex ante unobservability of candidates' abilities exposes firms to the risk of a mismatch. These are costly for firms. The role of the employment protection legislation here has been both theoretically and empirically well documented (Autor et al. (2007); Kugler and Saint-Paul(2004)). But ALMPs, and in particular counseling and monitoring, can also play an important role in alleviating these difficulties. Acting as intermediary on the labour market, the public employment service can help reducing search costs for employers, increasing the number of active job seekers, and improving the employer-employee matching process through several channels.

First, if effective, job search assistance helps the unemployed at finding job offers, and monitoring helps at maintaining a certain level of search activity. As a result, unemployed workers would send more applications, so firms would open more vacancies and would be more likely to meet and hire unemployed workers. Gautier et al. (2012) indeed show that increased counseling and job search assistance slightly increases the stock of vacancies.

Second, job search assistance may also help the beneficiaries at directing their applications to offers which suit best their qualifications. If so, ALMPs generate a better employer-employee match and have a positive effect on firms' performance. However, as recent evidence shows, the existence of a compulsion effect may counteract this positive effect on the employer-employee match quality (Van Ours (2007)). Increased monitoring and sanctions have been shown to have a negative effect on post-unemployment outcomes of participants (Van den Berg and Vikström (2009)) ; Arni et al. (2012)). Moreover, the compulsory participation in activation programmes may create a leisure tax on the participants (Rosholm and Svarer (2008)). As a results, ALMPs may lower the value of unemployment and push people back to work, without concerns about the match quality. By pushing lower productivity workers back to work, ALMPs may diminish labour productivity. Lastly, if counseling affects the number of applications sent by unemployed workers, but not where they are sent to, then firms would experience an increase in the reviewing cost which also could adversely affect their economic performance (DeVaro (2005)). Then, the effect of ALMPs on firms' performance becomes an empirical question.

We offer to empirically evaluate the effect of ALMPs on firms' performance in the context of Denmark. Denmark is known for its flexicurity system introduced in 1994, which combines flexible hiring and firing regulations, generous unemployment insurance and social security net, and extensive active labour market policies (Anderson and Svarer (2007)). In this setup, intensification of activation policies has been consistently shown to have a strong positive effect on exit rates from unemployment for 
participants (see for example Graversen and van Ours (2008) and Rosholm (2008)). But the empirical evidence of both a compulsion effect on participants and a congestion effect on non participants, sheds doubt on the facts that firms hire more unemployed workers and have better market performance, when the provision of ALMPs increases.

We use the Danish linked employer-employee data, which provides a unique panel of firms and workers, combined with accounting data. Because we expect firms' workforce composition to be endogenous to their performance, we use a large-scale social experiment conducted in Denmark in Winter 2005/2006 that provided exogenous increase in the provision of ALMPs for firms hiring in the treated regions. We implement a panel Difference-in-Difference strategy to evaluate whether this increased provision of ALMPs changes hiring strategies of firms in favor of the unemployed, which, in turn, would lead to changes in firms' workforce compositions and affect various measures of firms' performance. We limit our analysis to small or medium-size firms, as they are most likely to be affected by the experiment.

We find that within a year following the experiment, small firms which labour markets were significantly affected by the experiment hire slightly more workers from the pool of unemployed and experience greater workforce turnover. Regarding firms' performance, we find that the experiment had no or only marginal detrimental effects on firms' value added per worker and productivity in the short run. These results run along with those found by Lechner et al. (2012) for the German case, and are consistent with the fact that the compulsion effect acts against the counseling effect, so that intensive counseling and monitoring improves the matching process, but neither the matching quality nor firms' performance.

The rest of the paper is organized as follows. Section 2 reviews the literature and propose a stylized matching model to underline the theoretical mechanisms. Section 3 presents the empirical question and strategy and section 5 discusses the results. Last, section 6 concludes.

\section{Related literature and theoretical mechanisms}

\subsection{Related literature}

In this section we present why ALMPs, and in particular counseling and job search assistance combined with monitoring and sanctions, may affect firms' hiring strategies and their economic performance. We abstract from other types of activation programmes, such as training, workfare and subsidized employment to be consistent with our empirical analysis. Our theoretical reasoning falls into the context where there are frictions in the labour market and heterogeneity of workers ex ante unobserved to the firm. Because counseling and monitoring may affect job search strategies of unemployed workers and the employer-employee matching process, it may affect the type and quality of applications a hiring firm receives, as well as the hiring decisions of the firm. It may thus affect the composition of the workforce which can, in turn, affect firm's performance. Hence, we posit that ALMPs can affect firms' performance through its effect on human resources practices. This mechanism is related to the one put forward by Autor et al. (2007) who show, using US data, that stricter employment protection due to the introduction of wrongful-discharge protections has a damageable effect on firm performance, because firing costs can induce firms to retain unproductive workers.

The hiring decision of a firm is made difficult and costly for several reasons. Greater frictions in the labour market make it more difficult to hire, so that the number of vacancies opened by firms is reduced (Pissarides (2000)). Moreover, in presence of ex ante uncertainty about workers' ability and match quality, hiring firms are exposed to the risk of a mismatch, which is more costly when the employment protection legislation if stricter, as shown by a number of studies. See for instance 
Pries and Rogerson (2005) for the effect of unemployment insurance, firing costs and minimum wage or Kugler and Saint-Paul(2004) for the analysis of firing costs on hiring and separating decisions. To circumvent this problem, firms can rely on a number of solutions. They can use the curriculum of applicants, that is the current and previous employment status, to get information about the applicants' ability. Firms can also hire through referrals (Rees (1966), Granovetter (1995), DeVaro (2008)) or rely on internal labour markets (Oyer and Schaefer (2010)).

Depending on the exposure of firms to shocks and on the activity in which they are involved, firms may be more or less risk-averse in their hiring decisions and face different types of applicants (Lazear (1998), Hendricks et al. (2003), Oyer and Schaefer (2010). In such a context, unemployed workers using the formal recruitment channel may be disadvantaged compared to job seekers who are employed or who are put in connection to the firms via their network. Empirical evidence and the theory indeed show that a firm which receives job applications from unemployed candidates and from employed workers that engage in on-the-job search tend to prefer contacting and hiring the employed candidate. One explanation for this is for instance that the unemployed status sends a negative signal on the applicants ability and productivity. Kugler and Saint-Paul(2004) give a theoretical foundation of this argument by showing that lower productivity workers, who produce a match of lower quality, are more likely to be separated from the firm than more productive worker. This means that the pool of unemployed candidates is expected to be composed of workers with lower ability. Empirically, Eriksson and Lagerström (2006) confirm this result by showing that compared to an otherwise identical employed applicant, an unemployed applicant is less likely to be contacted by a firm, indicating that firms favor employed applicants and may see the unemployment status as a signal of lower productivity.

Counseling and monitoring can help reducing this disadvantage imposed on unemployed workers. First, counseled and monitored workers search more actively and can send more applications because counseling reveals job offers. We refer to this effect as a quantitative effect of ALMPs on search activity. In presence of counseling and monitoring, firms are more likely to be contacted by unemployed workers and could therefore be more likely to hire them. Because there are more applicants, there is less market tightness and firms can open more vacancies. Gautier et al. (2012) indeed find a small positive effect of intensified ALMPs on the stock of vacancies. On the other hand, if AMLPs increase the number of unemployed actively looking for jobs, firms may be crowded with noisy and irrelevant applications and would not necessarily hire more unemployed workers (DeVaro (2005)). Experimental evidence suggests that firms do not necessarily hire more unemployed workers when ALMPs are intensified. Gautier et al. (2012) and Crépon et al. (2011) show evidence of a congestion effect or a change in the job queueing: if ALMPs increase the reemployment rate of participants, they reduce exit from unemployment for non-participants, indicating that intensified counseling and monitoring might not make firms hire more unemployed workers, but would rather make them hire different unemployed workers, those participating in programmes.

One can expect an additional qualitative effect of counseling: counseled workers could better direct their job applications. So one can expect to find better matches. The growing literature on postunemployment outcomes tends to show that counseling can increase the quality of the match. The primary unit of interest in these evaluations on post-unemployment outcomes is the individual, but if ALMPs affect post-unemployment outcomes, then it means that they may affect the hiring and firing strategies or the performance of firms. Results in this context are mixed and depend on the type of programme evaluated. van Ours (2002) shows that the separation rate from a new job is significantly reduced when the worker previously participated in ALMPs. On the other hand, a compulsion effect can counteract this positive effect, as it lowers the value of unemployment and pushes people back to work. A number of studies has indeed shown that monitoring and sanctions would worsen various post-unemployment outcomes (Van den Berg and Vikström (2009) for Sweden and Arni et al. (2012) 
for Switzerland). Eventually, the net effect of ALMPs on the match quality will depend on whether the quantitative effect is combined with a qualitative effect and on whether the latter is dominated by the compulsion effect.

ALMPs might affect firms' market outcomes because they may lead to different composition of applicants in terms of productivity and they may change the match quality. Oyer and Schaefer (2010) point out the need for additional research that documents across-firms variations in hiring strategies and a theoretical framework on the firm-level recruitment and hiring strategies, as it may help explaining the persistent firm-level conditional differences observed in profitability. A growing empirical literature shows that diversity in the workforce demographic composition along several dimensions has an effect on firms' outcomes. See for instance, Parrotta and Pozzoli (2012) for the influence of cultural, demographic and skill diversity of workforce on firm productivity in Denmark, Weber and Zulehner (2009), Weber and Zulehner (2010), Smith et al. (2006), Matsa and Miller (2010) and Ahern and Dittmar (2012) for hiring behaviour towards women, gender composition of the workforce and mandated female board representation on firms' performance, or Grund and Westergaard-Nielsen (2008) and Ilmakunnas and Ilmakunnas (2010) for age structure in the firm. There is however a lack of empirical evidence on the effect of workforce diversity in terms of labour market and ALMPs participation histories on firms' performance . Lechner et al. (2012) is to our knowledge the only existing study that provides such empirical evidence. They use local variations in the provision of ALMPs in Germany to evaluate how a number of programmes affect a variety of firm's outcomes, collected with survey information. They show that ALMPs tend to have no or negative effects on firms' performance. The present paper is most related to this last contribution.

\subsection{Theoretical Intuitions in a simple job matching model}

The theoretical framework presented in this section is built to capture the link between the intensity of ALMPs, employment flows, vacancies and firm's productivity. The main stress is put on firm's decisions to open vacancies and to show how ALMPs may affect this decision along with firm's value.

We consider a representative firm which can freely open vacancies to produce an output. It can hire an unemployed job seeker to fill the position. The probability of being matched to a job seeker depends on the market tightness $\theta=\frac{U}{V}$, that is on the ratio of the number of active job seekers $U$ to the number of vacancies $V$. It also depend on the intensity of ALMPs. We consider two policy contexts, one with intensive ALMPs, denoted as $D=1$, and one with regular ALMPs, denoted as $D=0$. Below we discuss how the policy context can affect the firm's decision. We introduce workers' heterogeneity and assume that the unemployed job seekers population is divided into two types of workers: "high productivity" workers (with productivity $\nu_{H}$ ) and "low productivity" workers (with productivity $\nu_{L}$ ), where $\nu_{H}>\nu_{L}$. The firm does not observe the applicant's specific productivity prior to forming a match, but it knows the distribution of productivities among the applicants. The match quality is revealed once the match is formed. The policy context affects the productivity composition of the active job seekers, so the share of high productivity unemployed workers, denoted as $p(D)$, depends on $D$.

The expected value $J_{e}$ of a job filled with a worker is given by:

$$
J_{e}(D)=p(D) J\left(\nu_{H}\right)+(1-p(D)) J\left(\nu_{L}\right),
$$

with $J\left(\nu_{H}\right)$ and $J\left(\nu_{L}\right)$ being the values of a firm that hires a worker of productivity $\nu_{H}$ and $\nu_{L}$ respectively. A position filled with a worker of productivity $\nu_{i}$, with $i=\{L, H\}$, produces $\nu_{i}$ output per unit of time. The worker is paid a wage $w$. The match is dissolved at a Poisson rate $\delta$ which is assumed exogenous for simplicity. Hence, the value of a firm matched with a worker of productivity 
$\nu_{i}, i=\{H, L\}$ is:

$$
r J\left(\nu_{i}\right)=\nu_{i}-w+\delta\left(V-J\left(\nu_{i}\right)\right)
$$

The value of a vacant firm is:

$$
r V=-C(D)+m(\theta, D)\left(J_{e}(D)-V\right),
$$

where $C(D)$ is the cost of searching for an unemployed worker and $m(\theta, D)$ is the matching function in the policy context $D$.

The firm creates a vacancy if it is profitable, that is as long as the cost of recruiting a worker is greater or equal to the expected gains of recruiting such a worker in the policy context $D$. The free-entry assumption brings this condition to equality. So we have:

$$
\frac{C(D)}{m(\theta, D)}=\frac{\left(p(D) \nu_{H}+(1-p(D)) \nu_{L}\right)-w}{r+\delta}
$$

The policy context which we analyze consists, most of all, of intensified counseling, job search assistance and monitoring. As discussed by the previous literature, this can have either a qualitative, or a quantitative effect, or both.

The quantitative effect (increase in the number of unemployed actively looking for a job) is positively reflected in the matching function $(m(\theta, 1)>m(\theta, 0))$. The qualitative effect (workers' search being better directed) is positively reflected in the distribution of productivity among the applicants faced by a single firm $(p(1)>p(0))$. In any case this would lead to firms hiring more unemployed workers and an improvement in firms' value.

The mechanism which can undermine these positive effects of an improved policy context is the compulsion effect. If unemployed are compulsory pushed into employment, we might observe an improvement in the matching function at the cost of the quality of the unemployed job seekers. In this case we have $(m(\theta, 1)>m(\theta, 0)$ and $p(1)<p(0))$ and one would observe firms hiring more workers from the pool of unemployed which would, however, push the firms' value down.

All in all, the final effect of an intensification of counseling and job search assistance is not clear. While we expect that firms operating in a region where the ALMPs are intensified would hire more unemployed job seekers, it is not clear what effect this would have on their economic performance. We turn to empirical analysis to answer this question.

\section{Empirical Analysis}

This section provides empirical evidence on the impact of intensive ALMPs on firms' hiring structure and economic performance. Relying on a large-scale social experiment conducted in Winter 2005-2006 in Denmark we can easily deal with selection problem typical for policy evaluation. Before we turn to the identification strategy and the data, let us describe the experiment in detail.

\subsection{Large scale experimental increase in ALMPs}

The social experiment exploited in this study was conducted in Winter 2005-2006 in two Danish regions, the Storstrøm and Southern Jutland counties. Despite the short period of the experiment, the treated population accounted for a significant share of eligible unemployed workers over the 4-month period in these regions, and the experiment involved a strong intensification of ALMPs, especially of counseling and monitoring, for the treated individuals. 
Workers assigned to the treatment group ${ }^{1}$ had to participate in a two-week Job Search Assistance (JSA) programme from weeks $5 / 6$ to week $7 / 8$ of unemployment, then ideally from the 7 th to the 18th week of unemployment, they had frequent meetings with a caseworker to ensure that they are searching actively and to assist them in this job search. Finally, those who have not found employment after 18 weeks of unemployment had to participate in an ex-ante unspecified programme for a minimum duration of 13 weeks. ${ }^{2}$ At the end of this programme, treated individuals went back to the regular activation with a meeting with a caseworker only once every 13 weeks from the date of entry in unemployment and participation in an unspecified programme after one year of unemployment. Treated individuals were informed about the the intensified ALMPs they are about to participate in, but neither the untreated individuals nor firms knew about the experiment.

About 5000 unemployed participated in the experiment and about 2300 individuals received the treatment (1200 in Storstrøm and 1100 in South Jutland). This accounts for a bit less than 50\% of insured unemployed who entered unemployment between November 2005 and February 2006 in these counties, and for $2.5 \%$ of the stock of unemployment in 2005Q4 in Fyn, Southern Jutland and Est Jutland, the regions we limit the analysis to. $30 \%$ of the treated individuals left unemployment during the first month (as opposed to $28 \%$ of non-treated) and $68 \%$ left unemployment during the first 18 weeks (as opposed to $61 \%$ or non-treated), so few treated individuals entered in the 13 -week scheme. As shown in Figure 3in the Appendix, in the experimental county we analyze, Southern Jutland, the treated workers faced much higher intensity of activation programmes during the second month of unemployment and met a caseworker about 3 times as often as the non-treated during the following months (Blasco and Rosholm (2011)).

The effects of this experiment on the treated individuals have been extensively analyzed. Rosholm (2008) shows that it had remarkable positive effects on the exit rate from unemployment for the treated individuals and Blasco and Rosholm (2011) find strong negative effect on unemployment recurrence for treated men. On the other hand, a recent study of the general equilibrium effects of this experiment (Gautier et al. (2012)) points to negative congestion effects for the untreated unemployed in the South Jutland region, which, however, are weaker than the positive effect on the treated. This suggests that the experiment has created a shock to the matching process and to the importance of the intermediary role played by the employment agency resulting in more hirings from the pool of unemployed in the treated regions. The effect of the experiment on firms hiring in the treated regions (the treated firms) has only been analyzed by Gautier et al. (2012) who show that in the two treated regions there was a slight increase in the total number of vacancies during the experiment. It implies that firms react to the increased number of unemployed actively looking for jobs by adjusting their hiring practices. Nevertheless, it is not clear how does this influence the treated firms' economic performance.

By activating the unemployed the experiment has increased the stock of unemployed job seekers and, as a result, it was easier for firms to hire from unemployment. This could have positive effects on firms' economic performance, because they could find workers at lower cost. On the other hand, the existing literature suggests that the increased job search activity of the unemployed during the social experiment can be significantly accounted for by the threat effect (Graversen and van Ours (2008)). Thus, it can happen that in expectation of intensified counseling workers tend to look for jobs faster and not spend much time on precisely addressing their applications. This could adversely affect the average quality of job applicants faced by the treated firms and, as a consequence, have a negative

\footnotetext{
${ }^{1}$ Randomization was based on birth dates in the month: those born on the $1^{\text {st }}$ to the $15^{\text {th }}$ were assigned to the treatment group, while those born on the $16^{\text {th }}$ to the $31^{\text {st }}$ were assigned to the control group.

${ }^{2}$ Treated could be allocated to 'private sector temporary employment subsidy jobs' (6 months), temporary employment within the public sector (6-12 months), classroom training programmes (the majority of programmes being shorter than 13 weeks) and vocational training programmes in firms (a few months).
} 
effect on their subsequent economic performance. ${ }^{3}$

\subsection{The data}

In our analysis we use information coming from two datasets which are merged using a unique firm identifier, so we construct a panel of firms containing economic as well as labour force information.

The first dataset is a rich register-based data from Denmark, the "Integrated Database for Labor Market Research" (IDA) provided by Statistics Denmark. This linked employer-employee data contains firm, workplace and individual identifiers, so it forms a panel of firms linked with a panel of employees. The firm panel provides rich information about the firm, like the sector and industry, size or ownership. The individual panel contains the socio-demographic characteristics, like gender, age, nationality, education, or district of residence for all individuals living in Denmark. For those aged 15-64, we additionally observe the labour market situation as well as the characteristics of the job and the identifier of the employing firm and workplace in case of employment as of November 30 each year. We aggregate individual-level data at the firm level to construct a panel of firms with such yearly information as firm employment level, demographic structure of its workforce, the geographic area where firm's workforce comes from, worker turnover characteristics, and the origin of newly hired workers (from another firm, from out of labour force, from unemployment).

The second dataset we use, the "Regnskab", contains firms' yearly business accounts. This dataset is collected in a form of a survey by Statistics Denmark. All firms with more than 50 employees and all firms exceeding a specified profits threshold are obliged to fill in the survey. The remaining firms are sampled using stratified sampling strategy. To avoid sampling issues, we only include firms with more than 20 employees in our analysis. The information we take from the "Regnskab" database contains firms' value added, capital stock, investments, and intermediate inputs.

The choice of the sample used in the empirical analysis is driven by the timing of the experiment and data availability. The "Regnskab" dataset is available till the year 2007, which allows us to analyze two years after the experiment (2006 and 2007). To assure comparability, we chose to analyze also two years before the experiment (2004 and 2005). Due to the fact that some variables are defined with one year lag, we limit our attention to firms which exist for at least two consecutive years and we include year 2003 in the initial sample. The experiment was implemented in two Danish counties, Southern Jutland and Stostrøm. However, a recent change in the administrative division of Denmark, resulting in a redefinition of location identifiers, does not allow us to clearly identify the Stostrøm county in our data. Thus, we drop individuals and firms operating in the new district that includes the former Stostrøm county. Last, we restrict our sample to firms with less than 200 employees $^{4}$, as these are the firms that are the most vulnerable to small changes in labour force composition. They also most likely to be affected by the experiment as they would benefit from more visibility thanks to increased counseling offered to the unemployed workers.

\subsection{Measurement of firms' outcome variables}

We are interested in the impact of the increased provision of ALMPs on two types of outcomes, namely the workforce-related outcomes (hiring composition and workforce turnover), and the market performance outcomes (productivity and value added).

\footnotetext{
${ }^{3}$ Note that firms did not know about the experiment, so they could not expect that the increased inflow of unemployed job seekers is a reaction to ALMPs intensification.

${ }^{4}$ We conducted the same analysis for larger firms. We find no significant effect of increased ALMPs in the short run on their hiring and performance outcomes. Results for larger firms are available upon request.
} 
To measure the hiring composition and turnover characteristics, we compute year-to-year employment flows at the firm level. For each firm $i$, we calculate the turnover $T O_{i t}$ for a given year $t$ as the share of new employees coming between November $t-1$ and November $t$ in the total stock of employees as of the end of November $t$. This measure is informative about both the growth of the firm and pure turnover. Because we are interested in knowing whether firms hire more unemployed workers due to an increase in the provision of ALMPs, for each year $t$, we also compute the share of new employees who were unemployed one year earlier. This measure, $S U_{i t}$, is only available for firms that hire new employees between November $t-1$ and November $t$.

Concerning market performance outcomes, we use two measures. First, we focus on firm-level value added to capture the effect of workforce composition on the value created by a firm. Value added is calculated as the difference between firm's total output and the value of inputs, as measured at the end of the calendar year. We measure value added per full-time employee and express it in log values. It is referred to as $V A P C_{i t}$. Second, we analyze firm-level total factor productivity (TFP) to check whether firms faced with increased provision of ALMPs optimally use their technology and resources. Total factor productivity is measured as the residual from firm-level production function estimation. We follow Wooldridge (2009) when estimating the production function. We use labour and capital as the main inputs, assuming that labour can react to short-time productivity shocks and thus use lagged values of labour inputs as instruments. Additionally, we use intermediate inputs, such as material and energy, as a proxy for investment levels (Levinsohn and Pertin (2003)) to partially control for timevarying productivity shocks. A third-degree polynomial of inputs is used to proxy for the unknown shape of the production function (Petrin et al. (2004)). We express TFP in log values and denote this measure by $T F P_{i t}$.

\subsection{Definition of the treatment and control groups}

We define the treated and control firms based on the county of residence of their workforce before the experiment has started. More precisely, we consider that the treated firms are the firms which, on average, between November 2004 and November 2005, were employing more than $33 \%$ of their workforce in the Southern Jutland county ${ }^{5}$. This definition of the control group allows us to account for the facts that firms usually hire workers in more than one county and the majority of their workforce might not come from the county where the firm is registered. Firms with a significant share of workforce coming from the treated region are most likely to be affected by the experiment. ${ }^{6}$ Hence, firms recruiting largely in South Jutland county belong to the treatment group and the years 2006 and 2007 (two years following the experiment) are the affected years. This results in about 3000 treated firms observed yearly.

The basic control firms are those which, on average, between November 2004 and November 2005, were employing more than two-thirds of their workforce in a geographical area that was not affected by the experiment, because they do not benefit from such a potential improvement of the search and general abilities of candidates coming from the pool of unemployed. We restrict the set of control firms to firms operating in regions most similar to South Jutland. As Figure 1 shows, East Jutland and Fyn regions experienced a similar evolution of local unemployment rate as the experimental region of South Jutland prior to the experiment. We limit our attention to these three regions. Thus, our final control sample consists of firms hiring less than 33\% of their workforce in South Jutland and at least $33 \%$ of their workforce in East Jutland or Fyn. This results in about 3000 control firms a year.

Table 1 shows the characteristics of the treated and control firms prior to the experiment. Note

${ }^{5}$ In section 4.3., we test the sensitivity of our results to this criterion.

${ }^{6}$ Lechner et al. (2012) use a similar strategy to identify firms facing policies implemented by regional job centers. 
that the group of comparison firms is in general very similar to the group of treated firms. The only important difference between these two groups can be observed in the share of previously unemployed in new hires: it appears that the treated firms hired less from unemployment before the experiment.

Table 1: Comparaison of treated and control firms' characteristics in 2005

\begin{tabular}{|c|c|c|}
\hline & Treated & Control \\
\hline \multicolumn{3}{|l|}{ Outcomes } \\
\hline TFP (log) & $\begin{array}{c}4.272 \\
(0.526)\end{array}$ & $\begin{array}{c}4.267 \\
(0.540)\end{array}$ \\
\hline Value added per worker (log) & $\begin{array}{c}5.326 \\
(0.669)\end{array}$ & $\begin{array}{c}5.434 \\
(0.715)\end{array}$ \\
\hline Turnover (\%) & $\begin{array}{c}0.080 \\
(0.252)\end{array}$ & $\begin{array}{c}0.086 \\
(0.263)\end{array}$ \\
\hline $\begin{array}{l}\text { Share of previously } \\
\text { unemployed in new hires }(\%)\end{array}$ & $\begin{array}{c}0.035 \\
(0.055)\end{array}$ & $\begin{array}{c}0.042 \\
(0.065)\end{array}$ \\
\hline \multicolumn{3}{|c|}{ Composition of current employees (\%) } \\
\hline Firm size & $\begin{array}{c}48.921 \\
(34.627)\end{array}$ & $\begin{array}{c}47.975 \\
(34.209)\end{array}$ \\
\hline Managers & $\begin{array}{c}0.051 \\
(0.084)\end{array}$ & $\begin{array}{c}0.064 \\
(0.111)\end{array}$ \\
\hline Blue collar workers & $\begin{array}{c}0.359 \\
(0.219)\end{array}$ & $\begin{array}{c}0.344 \\
(0.222)\end{array}$ \\
\hline Women & $\begin{array}{c}0.319 \\
(0.265)\end{array}$ & $\begin{array}{c}0.335 \\
(0.258)\end{array}$ \\
\hline Foreigners & $\begin{array}{c}0.052 \\
(0.080)\end{array}$ & $\begin{array}{c}0.055 \\
(0.097)\end{array}$ \\
\hline University graduates & $\begin{array}{c}0.566 \\
(0.201)\end{array}$ & $\begin{array}{c}0.582 \\
(0.205)\end{array}$ \\
\hline Vocational school graduates & $\begin{array}{c}0.005 \\
(0.014)\end{array}$ & $\begin{array}{c}0.006 \\
(0.018)\end{array}$ \\
\hline Primary school graduates & $\begin{array}{c}0.313 \\
(0.158)\end{array}$ & $\begin{array}{c}0.312 \\
(0.170)\end{array}$ \\
\hline \multicolumn{3}{|c|}{ Composition of employees in the previous year (\%) } \\
\hline Firm size & $\begin{array}{c}46.746 \\
(35.523)\end{array}$ & $\begin{array}{c}48.676 \\
(37.569)\end{array}$ \\
\hline Managers & $\begin{array}{c}0.051 \\
(0.087)\end{array}$ & $\begin{array}{c}0.065 \\
(0.113)\end{array}$ \\
\hline Blue collar workers & $\begin{array}{c}0.364 \\
(0.223)\end{array}$ & $\begin{array}{c}0.352 \\
(0.223)\end{array}$ \\
\hline Women & $\begin{array}{c}0.312 \\
(0.262)\end{array}$ & $\begin{array}{c}0.334 \\
(0.258)\end{array}$ \\
\hline Foreigners & $\begin{array}{c}0.048 \\
(0.079)\end{array}$ & $\begin{array}{c}0.050 \\
(0.097)\end{array}$ \\
\hline University graduates & $\begin{array}{c}0.572 \\
(0.200)\end{array}$ & $\begin{array}{c}0.587 \\
(0.206)\end{array}$ \\
\hline Vocational school graduates & $\begin{array}{c}0.004 \\
(0.013)\end{array}$ & $\begin{array}{c}0.005 \\
(0.018)\end{array}$ \\
\hline Primary school graduates & $\begin{array}{c}0.312 \\
(0.162)\end{array}$ & $\begin{array}{c}0.312 \\
(0.172)\end{array}$ \\
\hline \multicolumn{3}{|l|}{ Other information } \\
\hline Share of production industry & $\begin{array}{c}0.285 \\
(0.452)\end{array}$ & $\begin{array}{c}0.252 \\
(0.434)\end{array}$ \\
\hline Observations & 3054 & 3005 \\
\hline
\end{tabular}




\subsection{The identification strategy}

The goal of our empirical analysis is to identify the effects of increased provision of ALMPs on the affected firms' outcomes. When estimating these treatment effects we come across the usual identification problems.

Let $Y_{i t}(d)$ be the outcome variable of firm $i$ measured in year $t$ in the policy context $D=d$, where $d=1$ denotes an environment with intensified ALMPs. The observed outcome is then $Y_{i t}=$ $D Y(1)+(1-D) Y(0)$. In this analysis, we concentrate on four firm outcomes, namely the share of previously unemployed in new hires, yearly workforce turnover, total factor productivity, and value added per worker. Thus, $Y_{i t} \in\left\{T O_{i t}, S U_{i t}, V A P C_{i t}, T F P_{i t}\right\}$. We are after the average treatment effect on firms that operate in a labour market with intensive ALMPs, i.e.:

$$
\delta=E\left(Y_{i t}(1) \mid D=1\right)-E\left(Y_{i t}(0) \mid D=1\right)
$$

The first term in the above expression is the observed outcome of a firm under intensive ALMPs (a treated firm), while the second term is the unobserved counterfactual, i.e. the outcome of this firm under usual provision of ALMPs. We proxy for the latter by the expected outcome of a control firm which never faced intensified ALMPs, $E\left(Y_{i t}(0) \mid D=0\right)$. To correctly identify the treatment effect we need to assure that the outcome of the control firms constitutes an unbiased proxy for the outcome control firms, i.e. that these firms do not differ in any characteristics which might influence the outcome variable.

One could expect that firms most likely to hire in labour markets with intensified counseling and monitoring are those that rely more on the unemployment pool to recruit new workers. This, in turn, might be correlated with their outcomes, independent on treatment. Because our goal is to evaluate how ALMPs may affect firms' performance, by possibly changing their hiring decisions and outcomes, our main concern is that the hiring decision is endogenous to performance. To give evidence of this selection, we regress the share of new hires coming from the pool of unemployed on various firms characteristics. The estimated correlations are reported in Table 2, where in the left panel we control for firms' value added and in the right panel for their TFP.

The correlation between firm performance and the share of new hires coming from the pool of unemployed is strong. One log point increase in the TFP or value added per employee is connected with 0.4 percentage point increase in hiring from the pool of unemployed, which corresponds to $10 \%$ increase. Also higher turnover rates are associated with more hiring from the pool of unemployed. Finally, firms hiring more in the pool of unemployed have, on average, older, less educated workforce and fewer females. Interestingly, these firms rely more on white collar workers. This suggests that some firms are consistently employing more unemployed workers of unknown productivity than others. Thus, we need to use an estimation strategy that will allow us to reduce, if not eliminate, this selection to correctly evaluate the effect of ALMPs on firms' performance. 
Table 2: Share of previously unemployed in new hires and firm characteristics

\begin{tabular}{|c|c|c|}
\hline \multicolumn{3}{|c|}{ Dependent variable: Share of previously unemployed in new hires } \\
\hline & $(1)$ & $(2)$ \\
\hline \multicolumn{3}{|l|}{ Firm outcomes } \\
\hline Turnover & $\begin{array}{c}0.012^{* * *} \\
(0.001)\end{array}$ & $\begin{array}{c}0.011^{* * *} \\
(0.001)\end{array}$ \\
\hline TFP & $\begin{array}{c}0.005^{* * *} \\
(0.001)\end{array}$ & \\
\hline Value added per worker & & $\begin{array}{c}0.005^{* * *} \\
(0.001)\end{array}$ \\
\hline \multicolumn{3}{|l|}{ Incumbents characteristics } \\
\hline Median age & $\begin{array}{c}0.001^{* * *} \\
(0.000)\end{array}$ & $\begin{array}{c}0.001^{* * *} \\
(0.000)\end{array}$ \\
\hline Share of females & $\begin{array}{c}-0.007^{* * *} \\
(0.001)\end{array}$ & $\begin{array}{c}-0.005^{* * *} \\
(0.001)\end{array}$ \\
\hline Share of college graduates & $\begin{array}{c}-0.006^{* *} \\
(0.002)\end{array}$ & $\begin{array}{c}-0.006^{* *} \\
(0.002)\end{array}$ \\
\hline Share of vocational graduates & $\begin{array}{c}-0.023^{*} \\
(0.012)\end{array}$ & $\begin{array}{c}-0.026^{* *} \\
(0.012)\end{array}$ \\
\hline Share of primary school graduates & $\begin{array}{c}-0.002 \\
(0.003)\end{array}$ & $\begin{array}{c}-0.002 \\
(0.003)\end{array}$ \\
\hline Share of managers & $\begin{array}{c}-0.007^{*} \\
(0.004)\end{array}$ & $\begin{array}{c}-0.008^{* *} \\
(0.004)\end{array}$ \\
\hline Share of blue collar workers & $\begin{array}{c}-0.013^{* * *} \\
(0.002)\end{array}$ & $\begin{array}{c}-0.013^{* * *} \\
(0.002)\end{array}$ \\
\hline constant & $\begin{array}{c}0.023 \\
(0.044)\end{array}$ & $\begin{array}{c}0.016 \\
(0.044)\end{array}$ \\
\hline
\end{tabular}

Note: Standard errors in parentheses; variable excluded due to colinearity: Share of white collars, share of high school graduates. Other controls included: year and industry dummies. All workforce characteristics are lagged one year. 
The social experiment conducted in Denmark in Winter 2005/2006 allows us to deal with this endogeneity problem by creating an exogenous increase in the provision of ALMPs. All firms operating in the treated regions are faced with unemployed job applicants who have high probability of being influenced by intensified ALMPs. Thus, we do not have to worry that firms endogenously choose to hire in an environment with stronger ALMPs. Nevertheless, there are still two concerns which might influence our estimates: the fact that firms interested in hiring from the pool of unemployed would be more affected by the experimental intensification in ALMPs, and the fact that the two treated counties have volunteered for hosting the experiment is problematic to us. As is presented in Figure 1, South Jutland (one of the experimental regions) faced visibly higher unemployment rate prior to the experiment than other Danish counties, even though the coverage of activation policies in this region was relatively large. For these reasons, we are careful in conditioning on a set of firm characteristics and in choosing our counterfactual (as in Gautier et al. (2012)). Most importantly, we restrict the comparison group to regions which experience similar trend in the evolution of unemployment as the experimental county, i.e. to West Jutland and Fun, and we apply fixed effects technique to deal with firms' time-constant propensity to hire in the pool of unemployed.

Figure 1: Evolution of the unemployment rate in the experimental and control counties

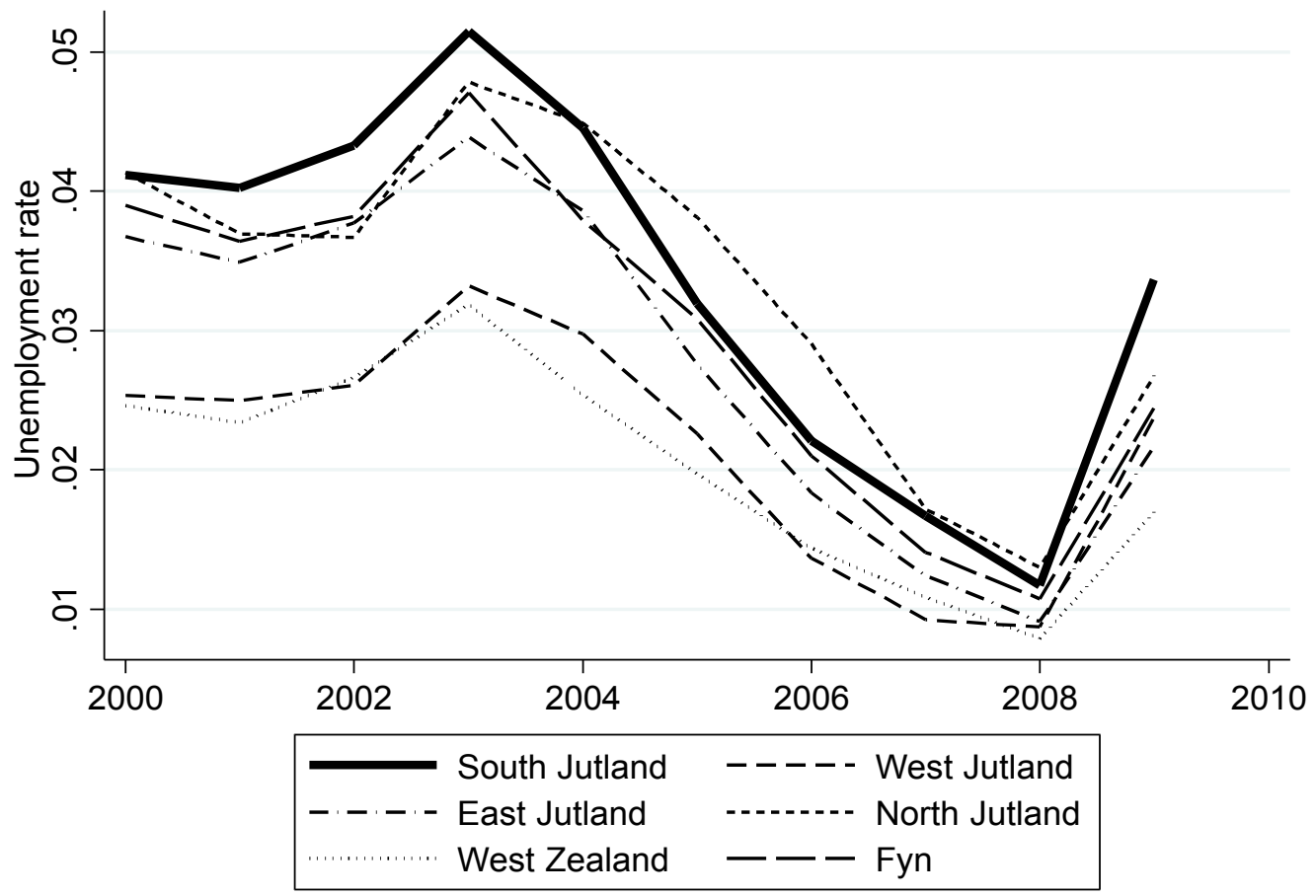

Thus, to measure how the experimental increase in counseling and monitoring influenced firms' outcomes, we differentiate the change in these outcomes before and after the experiment between firms hiring mainly in the experimental region and firms hiring mainly in the control regions. In the classical Difference-in-Difference approach, we make no use of the panel dimension and estimate the following regression with OLS: 


$$
Y_{t i j}=\delta R_{j} \times T_{t}+\gamma R_{j}+\lambda T_{t}+\beta X_{t i j}+u_{t i j}
$$

with $R_{j}$ the regional dummy that equals 1 if the firm is used to hired more that $33 \%$ of its workforce in the experimental region, and 0 otherwise, $T_{t}$ the the dummy indicating whether the year of observation is the experiment year (2005-2006), and $X_{t i j}$ a set of firm's $i$ characteristics. The regional and year dummies control, respectively, for systematic heterogeneity between the treated and untreated regions and for time trends that can affect, independent on the experiment, the outcome variable. The parameter $\delta$ associated with the interaction term identifies the treatment effect under the identifying assumption which is the common trend assumption: in the absence of the experiment, firms hiring more in the experimental region have the same evolution in the outcome $Y$ as firms relying more on the non experimental regions.

We graph the evolution of two out of four firm outcomes (share of previously unemployed in new hires and value added per worker) before and after the experiment (Figure 2). ${ }^{7}$ The pre-treatment trends for the treated and control firms are alike, supporting the common trend assumption. Starting from the experiment period, there is some discrepancy in the trends between the two groups.

\footnotetext{
${ }^{7}$ We plot time evolution for these outcomes which we observe for at least 3 years before the experiment.
} 
Figure 2: Evolution of the outcome variables in the experimental and control counties SU

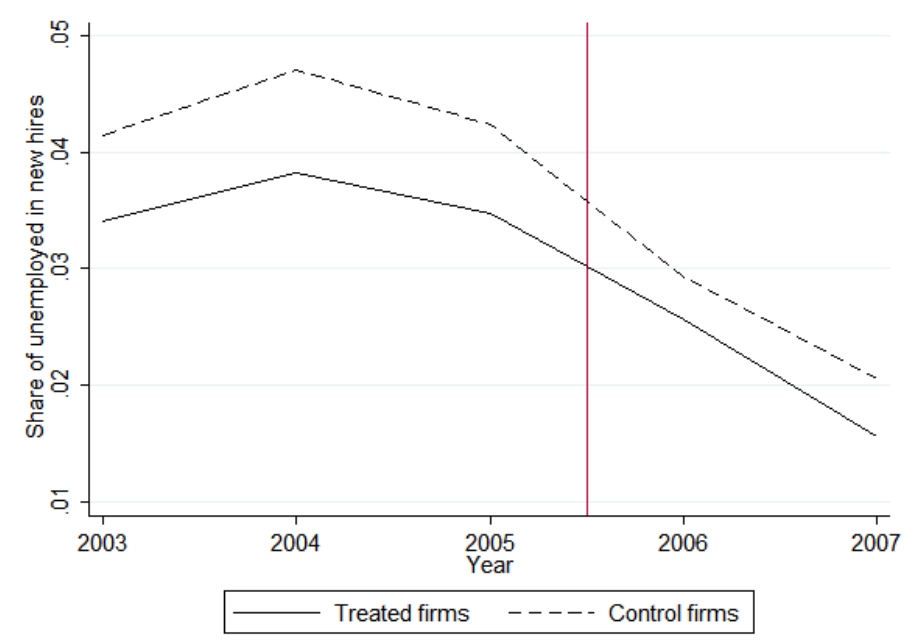

VAPC

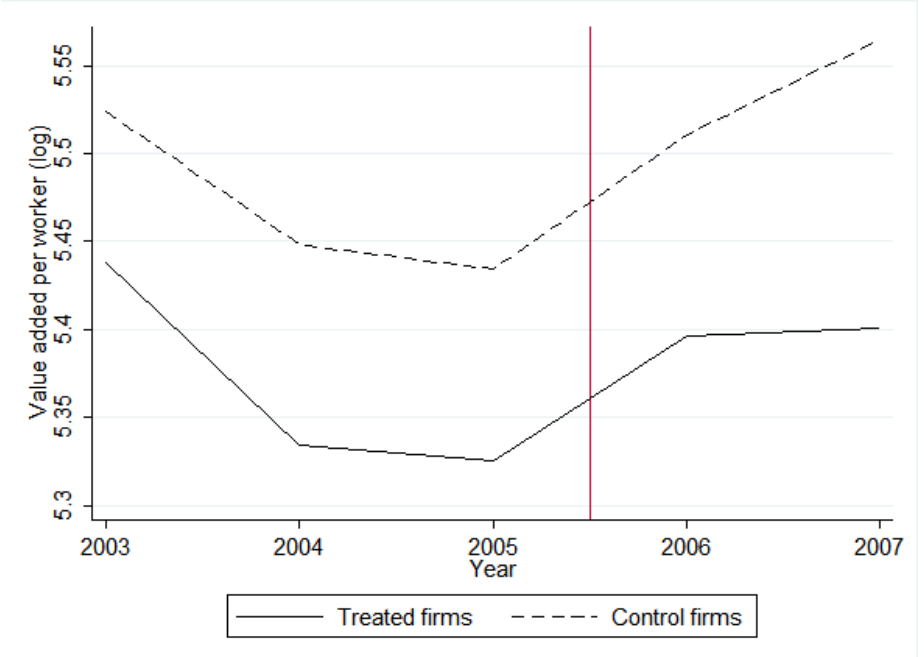


Because we have a panel of firms, we can implement a Difference-in-Difference with firms' fixed effect. The fixed-effect Difference-in-Difference approach is our preferred specification because it allows for controlling for systematic differences between firms.

\section{Results}

\subsection{The impact of increased ALMPs on the hiring strategy}

We start by evaluating the effect of increased counseling on hiring strategies, measured by the turnover, $T O$, and the share of newly hired who come from unemployed, $S U$. For both outcomes, the set of control variables $X_{i j t}$ contains industry dummies and the workforce socio-demographic characteristics of the firm $j$ in $t-1$ (educational and occupational structures, distribution of age of employees and the share of women among employees in $t-1$ ). The estimated parameters of main interest are reported in Table 3. The full set of estimated parameters are displayed in Appendix in Table 6.

Table 3: Interaction term in the DiD equation on firm-level hiring outcomes

\begin{tabular}{lcccc}
\hline \hline \multicolumn{4}{c}{ Dependent variable } \\
\hline & DiD & FE DiD & DiD & FE DiD \\
\hline \multirow{3}{*}{ Interaction } & $0.079^{* * *}$ & $0.011^{* *}$ & $0.007^{* * *}$ & $0.004^{* *}$ \\
& $(0.004)$ & $(0.004)$ & $(0.001)$ & $(0.002)$ \\
& & & & \\
\hline \hline
\end{tabular}

\begin{tabular}{l}
\hline \hline Note: Standard errors in parentheses. Controls included: year, \\
hiring region, industry dummies and workforce characteristics \\
which are lagged one year. Threshold value for the assignation \\
to the treatment group: $33 \%$.
\end{tabular}

Overall, an increase in ALMPs has a significant positive effect on workforce turnover, even when we account for firms' fixed effects. This higher turnover for treated firms may be due to two mechanisms. First, it might be driven by increased labour force inflow due to intensified counseling and monitoring reducing matching frictions. Second, it might be driven by the fact that newly hired unemployed are less productive and generate a match of low quality, which would be consistent with the idea that a compulsion effect damages the match quality. In any case, we would observe a higher workforce turnover.

An increase in ALMPs has also a significant positive effect on the share of previously unemployed in new hires among firms which hire at least one new worker. Accounting for firms fixed effects reduces the size of the estimated coefficient, but we still observe a positive and significant effect. This is consistent with the existing literature on individual outcomes which shows that the experiment increased exit rates from unemployment for participants (?) and that this positive effect on the treated is not compensated by the negative effect found for the untreated (Gautier et al. (2012)). Based on the FE DiD estimate, we can conclude that intensive counseling and monitoring implemented in the region where the firm tend to recruit workers increases the share of new employees coming from unemployment by 0.4 percentage points. Given that, on average, $4 \%$ of the new hires come from unemployment, the increase due to the experiment accounts for $10 \%$ of the average share of previously unemployed in the new hires, which is noticeable.

The comparison between the classical DiD and the Panel DiD reveals a positive selection: treated firms have some characteristics that make them prefer hiring in the experimental region and at the same time rely more on previously unemployed workers. Because they tend to look for this kind of workers, they benefit more from intensive ALMPs than the other firms. Once we control for this 
systematic difference in hiring practices, thanks to the fixed effect approach, the estimated effect of intensified ALMPs is reduced.

\subsection{The impact of increased ALMPs on firms' performance}

We now turn to the effect of increased ALMPs on firms' market performance, measured by the value added per worker, $V A P C$, and the TFP measure, $T F P$, both expressed in log. For each outcome, the set of control variables $X_{i j t}$ contains industry dummies and the workforce socio-demographic characteristics of the firm $j$ in the current year $t$ (educational and occupational structures, distribution of age of employees and the share of women among employees in $t$ ). Table 4 reports the estimated parameters of main interest. The full set of estimated parameters are displayed in Appendix in Table 7.

Table 4: Interaction term in the DiD equation on firm-level performance outcomes

\begin{tabular}{lcccc}
\hline \hline Dependent variable & \multicolumn{2}{c}{ VAPC } & \multicolumn{2}{c}{ TFP } \\
\hline \multirow{3}{*}{ Interaction } & DiD & FE DiD & DiD & FE DiD \\
& & & & \\
& $-0.145^{* * *}$ & 0.002 & $-0.120^{* * *}$ & $-0.018^{* * *}$ \\
& $(0.008)$ & $(0.006)$ & $(0.006)$ & $(0.005)$ \\
\hline \hline
\end{tabular}

Note: Standard errors in parentheses. Controls included: year, hiring region, industry dummies and workforce characteristics for the current year. Threshold value for the assignation to the treatment group: $33 \%$.

Whichever the measure of performance is considered, the classic DiD approach shows that increased activation has a significant detrimental effect on the performance of small and medium firms. However, when we account for selection on unobservables with the panel DiD strategy, the effect of intensified activation on value added per worker disappears. The effect on the TFP remains significant and negative, but it becomes ten times smaller when selection on unobservables at the firm level is controlled for. Given that the mean TFP is about 4, the fact that the experiment reduced the TFP of affected firms by 0.018 means that increased counseling and monitoring reduced the mean TFP by $0.45 \%$, which is negligible. These results are in line with those obtained by Lechner et al. (2012) who find that counseling and job search assistance programmes have no effect on firms' performance in Germany.

This non-positive effect of monitoring and counseling on small and medium firms may find several explanations. First, remember that the estimated effects are of a short term nature, as the outcome is measured at most one and a half year after the experiment took place. We showed that the treated firms tend to have more turnover and to hire more unemployed workers. When hiring more unemployed, workers who tend to have more difficulties on the labour market, firms' performance in the short run may be reduced due to the adaptation period (e.g. training of the newly hired). Second, nonpositive effect on performance is consistent with the fact that compulsion and quantitative effects act against the qualitative and matching effects: counseling and monitoring push to job workers of lower quality. Moreover, the compulsion effect may make workers sending application without concerns for the match quality. As a results, due to the increased activation, firms receive more applications from lower productivity or less appropriate workers, which may have a negative effect on their performance.

In the final set of regressions, we control for the share of previously unemployed in new hires to neutralize the effect of the experiment on firms's performance through increased inflows from unemployment (the quantitative effect). When conditioning on the composition of inflows, the interaction term is driven by the effect of the experiment on the match quality or the quality of the newly hired workers. Table 4 shows the estimated parameters of main interest. The full set of estimated parameters are displayed in Appendix in Table 8.

When we control for the composition of the newly hired, the treated firms still have poorer or 
Table 5: Interaction term in the DiD equation on firm-level performance outcomes with control for the share of previously unemployed in new hires

\begin{tabular}{lllll}
\hline \hline Dependent variable: & \multicolumn{2}{c}{ VAPC } & \multicolumn{2}{c}{ TFP } \\
\hline & DiD & FE DiD & DiD & FE DiD \\
\hline \multirow{2}{*}{ Interaction } & $-0.160^{* * *}$ & 0.007 & $-0.122^{* * *}$ & $-0.009^{*}$ \\
& $(0.008)$ & $(0.006)$ & $(0.007)$ & $(0.005)$ \\
Share of previously & $-0.132^{* * *}$ & -0.002 & $-0.057^{* * *}$ & $-0.061^{* * *}$ \\
unemployed in new hires & $(0.015)$ & $(0.014)$ & $(0.014)$ & $(0.013)$ \\
& & & & \\
\hline \hline
\end{tabular}

Note: Standard errors in parentheses. Controls included: year, hiring region, industry dummies and workforce characteristics for the current year. Threshold value for the assignation to the treatment group: $33 \%$.

unchanged economic performance. These results confirm that part of the estimated effect of intensified ALMPs on firms' performance is due to the fact that the experiment makes firms hire more unemployed workers. As the interaction effect remains significant for the TFP, we can conclude that part of the decrease in performance comes from the compulsion effect of monitoring and sanctions, what undermines the qualitative effect of job search assistance and counseling.

\subsection{Sensitivity analysis}

We perform a sensitivity analysis to test the robustness of our results to the choices made in the definition of the treatment and control groups. We first consider as treated the firms which hire at least $50 \%$ of their workforce in the experimental region. Second, we restrict our comparison group to firms that hire less than $25 \%$ of their workforce in the experimental region, excluding from the control group firms that are very close to the threshold value. Both analyses give qualitatively the same results as our baseline specification (Tables 9 and 10 in Appendix).

Lastly, we performed a placebo test, assuming that the experiment took place in a county where no shock to ALMPs happened. Not passing this test, that is finding a significant parameter associated to the placebo interaction term, would cast doubt on the fact that the estimates discussed in the previous section measure the causal effect of the experiment. Table 11 in Appendix shows that the test is passed for three out of four of the outcome variables in the panel Difference-in-Difference specification. Finding significant, though much smaller, effects of a placebo treatment on TFP might suggest that in fact the increased provision of ALMPs has no effect on treated firms' productivity. Nevertheless, this is still consistent with the hypothesis that compulsion effect acts against the expected positive effect of increased provision of ALMPs.

\section{Conclusion}

In this article, we extent the evaluation of active labour market programmes to firms' outcomes. The empirical evaluation literature tends to show that ALMPs affect both unemployment durations and reemployment stability of individual participants, indicating that ALMPs help improving the matching process, the match quality and/or the employability of unemployed workers. Although understanding the behaviour of the demand side of the market is also crucial for a comprehensive evaluation of the ALMPs, there are only very few studies that investigate how ALMPs affect firms' hiring behaviour and, especially, their economic performance.

We present a simple theoretical framework to explain how ALMPs can change the terms of the recruitment decision in a context where there is ex ante unobserved heterogeneity of unemployed job 
seekers. Our theoretical predictions indicate that if the intensity of counseling and monitoring increases, firms hire more workers from the pool of unemployed. The effect on their economic performance is, however, not clear. This is why we turn to the empirical analysis. Using an exogenous variation in the intensity of activation provided by a large-scale social experiment that was implemented in two Danish regions in 2005/2006, we evaluate the effects of increased job search assistance, monitoring and sanctions for small and medium-size firms.

First, we check whether the theoretical prediction of increased hiring from the pool of unemployed when faced with an increased provision of ALMPs can be observed in the data. We show that the large experimental increase in counseling and monitoring leads to an increase in the share of unemployed workers among the newly hired for the affected firms. It also produce greater turnover in treated firms than in comparable untreated firms. Second, we evaluate the effect of the experimental intensification in ALMPs on firm performance. We find that small and medium firms are negatively affected or not affected at all by increase in counseling and monitoring in their hiring regions. These non-positive effects are only partially driven by the fact that the affected firms hire more unemployed job seekers, suggesting that we observe two channels. First, the affected firms hire more unemployed and thus might be forced to spend more resources on training their new workers. Second, the workers hired by the affected firms are, on average, less productive due to the compulsion effect.

The analysis presented in this paper has one important limitation. The identified effects are responses to one shot experimental increase in the provision of ALMPs in the setup where firms did not know about the intervention. While this allows us to obtain robust estimates of these effects, it is not clear whether our findings can be generalized.

\section{References}

Ahern K.R. \& Dittmar A.K., 2012. The changing of the boards: the impact on firm valuation of mandated female board representation. The Quarterly Journal of Economics 127, 137-197.

Andersen T.M. \& Svarer M. 2007. Flexicurity - labour market performance in Denmark", CESifo Economic Studies 53 (3), 389-429.

Arni P., Lalive R. \& van Ours J.C., 2012. How effective are unemployment benefit sanctions? looking beyond unemployment exit. Journal of Applied Econometrics, Early view.

Autor D.H., Kerr W.R. \& Kugler A.D., 2007. Do employment protections reduce productivity? Evidence from U.S. States. NBER Working Papers 12860, National Bureau of Economic Research, Inc.

Blasco S. \& Rosholm M., 2011. The impact of active labour market policy on post-unemployment outcomes. Evidence from a social experiment in Denmark. IZA Discussion Papers 5631, Institute for the Study of Labor, Bonn.

Card D., Kluve J., Weber A., 2010. Active labour market policy evaluations: A meta-analysis. The Economic Journal 120 (548), F452-F477.

Crépon B., Duflo E., Gurgand, M., Rathelot R. and Zamora P., 2012. Do labour market policies have displacement effect? Evidence from a clustered randomized experiment. mimeo.

DeVaro, J., 2005. Employer recruitment strategies and the labour market outcomes of new hires. Economic Inquiry 43, 263-282.

DeVaro J., 2008. The labour market effects of employer recruitment choice. European Economic Review. 52 (2), 283-314.

Eriksson S. \& Lagerström J., 2006. Competition between employed and unemployed job applicants. Swedish evidence. Scandinavian Journal of Economics 108(3), 373-396. 
Marc Ferracci M., Jolivet G. \& van den Berg G.J., 2010. Treatment evaluation in the case of interactions within markets. IZA Discussion Papers 4700, Institute for the Study of Labor, Bonn.

Gautier P., Muller M. , van der Klaauw B., Rosholm M. \& Svarer M., 2012. Estimating equilibrium effects of job search assistance. IZA Discussion Papers 6748, Institute for the Study of Labor, Bonn.

Granovetter M., 1995. Getting a job: A study of contacts and careers. 2nd ed. Harvard University Press, Cambridge.

Graversen B.K. and van Ours J.C., 2008. Activating unemployed workers works; Experimental evidence from Denmark. Economics Letter 100, 308-310.

Grund C. \& Westergaard-Nielsen N., 2008. Age structure of the workforce and firm performance. International Journal of Manpower 29 (5), 410-422.

Hendricks, W., DeBrock, L. \& Koenker, R., 2003. Uncertainty, hiring and subsequent performance. The NFL draft. Journal of Labor Economics 21, 857-886.

Ilmakunnas P. \& Ilmakunnas S., 2010. Diversity at the workplace. Whom does it benefit?, mimeo.

Kluve J., 2010. The effectiveness of European active labour market programmes. Labour Economics 17, 904-918.

Kugler A. \& Saint-Paul G., 2004. How do Firing costs affect worker flows in a world with adverse selection?. Journal of Labor Economics 22 (3), 553-584.

Lazear E.P., 1998. Hiring risky workers. In internal labour market, incentives, and employment. Edited by Isao Ohashi and Toshiaki Tachibanaki. New York: St. Martin's.

Lechner M., Scioch P. \& Wunsch C., 2012. Do firms benefit from active labour market policies?. mimeo.

Levinsohn J. \& Petrin A. Estimating production functions using inputs to control for unobservables. Review of Economic Studies 70, 317-341.

Oyer P. \& Schaefer S., 2010. Personnel economics. Hiring and incentives, The Handbook of Labor Economics, Vol. 4, Ashenfelter and Card, eds.

Matsa, D.A. \& Miller A.R., 2010. A female style in corporate leadership? Evidence from quotas. Available at SSRN: http://ssrn.com/abstract=1636047 or http://dx.doi.org/10.2139/ssrn.1636047.

Parrotta P \& Pozzoli D., 2012. The effect of learning by hiring on productivity. The RAND Journal of Economics 42, 167185.

Petrin A., Levinsohn J. \& Poi B., 2004. Production function estimation in Stata using inputs to control for unobservables. Stata Journal 4, 113-123.

Pissarides C., 2000. Equilibrium unemployment theory. 2nd ed. MIT Press, Cambridge.

Pries M. \& Rogerson R., 2005. Hiring policies, labour market institutions, and labour market flows. Journal of Political Economy 113 (4), 811-839.

Rees A., 1966. Information networks in labour markets. American Economic Review (Papers and Proceedings) 56, 559-66.

Rosholm M., 2008. Experimental evidence on the nature of the Danish employment miracle. IZA Discussion Paper 3620, Institute for the Study of Labor, Bonn. 
Rosholm M. and Svarer M., 2008. Estimating the threat effect of active labour market programmes. Scandinavian Journal of Economics. 110 (2), 385-401.

Smith N., Smith V. \& Verner M., 2006. Do women in top management affect firm performance?A panel study of 2,500 Danish firms. International Journal of Productivity and Performance Management 55 (7), 569-593.

Van den Berg G.J. \& Vikström J., 2009. Monitoring job offer decisions, punishments, exit to work, and job quality, IZA Discussion Paper 4325, Institute for the Study of Labor, Bonn.

Van Ours J.C., 2007. Compulsion in active labour market programmes. National Institute Economic Review 202, 67-78.

van Ours J.C., 2002. The Locking-in Effect of Subsidized Jobs", IZA Discussion Paper No. 52.

Weber A. \& Zulehner C., 2009. Competition and gender prejudice. Are discriminatory employers doomed to fail?. mimeo.

Weber A. \& Zulehner C., 2010. Female hires and the success of start-up firms. American Economic Review. Papers \& Proceedings 100, 358-361.

Wooldridge J.M., 2009. On estimating firm-level production functions using proxy variables to control for unobservables. Economics Letters 104, 112-114. 


\section{Appendix}

Figure 3: Evolution of treatment intensity by group in Southern Jutland

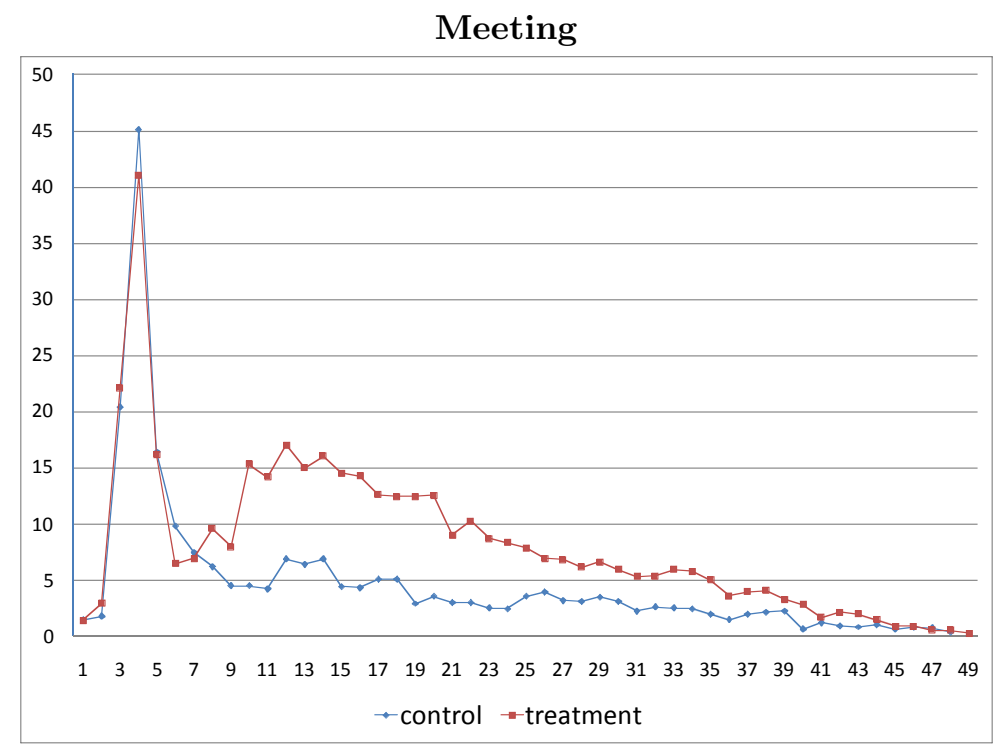

\section{Activation programmes}

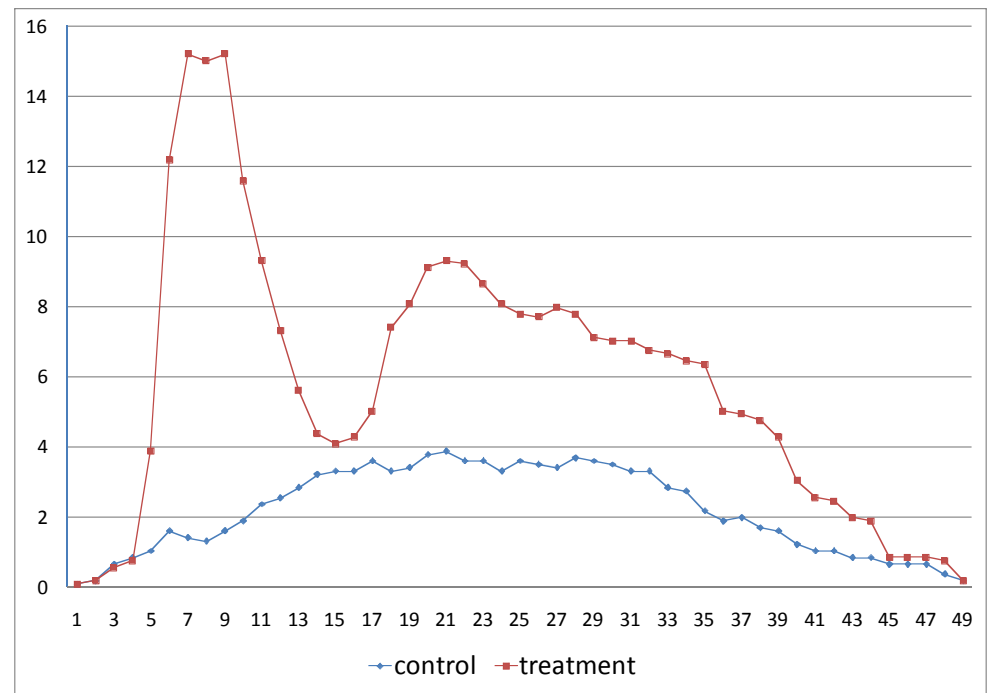


Table 6: The effect of ALMPs experiment on firm-level hiring outcomes - DiD analysis

\begin{tabular}{|c|c|c|c|c|}
\hline \multirow[t]{2}{*}{ Dependent variable: } & \multicolumn{2}{|c|}{ Turnover } & \multicolumn{2}{|c|}{$\overline{\mathrm{SU}}$} \\
\hline & DiD & FE DiD & DiD & FE DiD \\
\hline Interaction & $0.079^{* * *}$ & $0.011^{* *}$ & $0.007^{* * *}$ & $0.004^{* *}$ \\
\hline & $(0.004)$ & $(0.004)$ & $(0.001)$ & $(0.002)$ \\
\hline Turnover & & $\begin{array}{c}0.006^{* * *} \\
(0.001)\end{array}$ & $\begin{array}{c}0.007^{* * *} \\
(0.001)\end{array}$ & \\
\hline \multicolumn{5}{|l|}{ Incumbent characteristics } \\
\hline Median age & $\begin{array}{c}-0.001^{* * *} \\
(0.000)\end{array}$ & $\begin{array}{c}0.012^{* * *} \\
(0.000)\end{array}$ & $\begin{array}{c}0.001^{* * *} \\
(0.000)\end{array}$ & $\begin{array}{c}-0.000^{*} \\
(0.000)\end{array}$ \\
\hline Share of females & $\begin{array}{c}-0.034^{* * *} \\
(0.003)\end{array}$ & $\begin{array}{c}-0.125^{* * *} \\
(0.012)\end{array}$ & $\begin{array}{c}0.000 \\
(0.001)\end{array}$ & $\begin{array}{l}-0.005 \\
(0.005)\end{array}$ \\
\hline Share of college graduates & $\begin{array}{c}0.003 \\
(0.006)\end{array}$ & $\begin{array}{c}0.158^{* * *} \\
(0.015)\end{array}$ & $\begin{array}{c}-0.019^{* * *} \\
(0.002)\end{array}$ & $\begin{array}{c}-0.016^{* * *} \\
(0.005)\end{array}$ \\
\hline Share of vocational graduates & $\begin{array}{c}0.010 \\
(0.024)\end{array}$ & $\begin{array}{c}0.300^{* * *} \\
(0.061)\end{array}$ & $\begin{array}{c}-0.019^{*} \\
(0.010)\end{array}$ & $\begin{array}{l}-0.037 \\
(0.025)\end{array}$ \\
\hline Share of primary school graduates & $\begin{array}{c}-0.038^{* * *} \\
(0.006)\end{array}$ & $\begin{array}{c}0.033^{* *} \\
(0.015)\end{array}$ & $\begin{array}{c}-0.015^{* * *} \\
(0.003)\end{array}$ & $\begin{array}{l}-0.005 \\
(0.005)\end{array}$ \\
\hline Share of managers & $\begin{array}{c}0.001^{* * *} \\
(0.000)\end{array}$ & $\begin{array}{l}0.001^{*} \\
(0.001)\end{array}$ & $\begin{array}{l}-0.000 \\
(0.000)\end{array}$ & $\begin{array}{c}-0.001^{* *} \\
(0.000)\end{array}$ \\
\hline Share of blue collar workers & $\begin{array}{c}0.000 \\
(0.000)\end{array}$ & $\begin{array}{c}0.000 \\
(0.000)\end{array}$ & $\begin{array}{c}0.000 \\
(0.000)\end{array}$ & $\begin{array}{l}-0.000 \\
(0.000)\end{array}$ \\
\hline Treated region & $\begin{array}{c}-0.026^{* * *} \\
(0.003)\end{array}$ & & $\begin{array}{c}-0.011^{* * *} \\
(0.001)\end{array}$ & \\
\hline \multicolumn{5}{|l|}{ Year } \\
\hline 2005 & $\begin{array}{c}-0.051^{* * *} \\
(0.003)\end{array}$ & $\begin{array}{c}-0.094^{* * *} \\
(0.003)\end{array}$ & $\begin{array}{c}-0.006^{* * *} \\
(0.001)\end{array}$ & $\begin{array}{c}-0.006^{* * *} \\
(0.001)\end{array}$ \\
\hline 2006 & $\begin{array}{c}-0.076^{* * *} \\
(0.003)\end{array}$ & $\begin{array}{c}-0.117^{* * *} \\
(0.004)\end{array}$ & $\begin{array}{c}-0.023^{* * *} \\
(0.001)\end{array}$ & $\begin{array}{c}-0.022^{* * *} \\
(0.001)\end{array}$ \\
\hline 2007 & $\begin{array}{c}-0.066^{* * *} \\
(0.003)\end{array}$ & $\begin{array}{c}-0.163^{* * *} \\
(0.004)\end{array}$ & $\begin{array}{c}-0.032^{* * *} \\
(0.001)\end{array}$ & $\begin{array}{c}-0.032^{* * *} \\
(0.001)\end{array}$ \\
\hline Industry & & & & \\
\hline Intercept & $\begin{array}{c}0.203^{* * *} \\
(0.074)\end{array}$ & $\begin{array}{c}-0.408^{* * *} \\
(0.016)\end{array}$ & $\begin{array}{c}0.067^{* * *} * \\
(0.026)\end{array}$ & $\begin{array}{c}0.068^{* * *} \\
(0.006)\end{array}$ \\
\hline
\end{tabular}

Note: Standard errors in parentheses; variables excluded due to colinearity: Share of white collar workers, Share of high school graduates, year 2004, Industry 1 (Agriculture and fishing). Coefficients for industries are not reported because they are all insignificant. Threshold value for the assignation to the treatment group: $33 \%$. 
Table 7: The effect of ALMPs experiment on firm-level performance outcomes - DiD analysis

\begin{tabular}{|c|c|c|c|c|}
\hline \multirow[t]{2}{*}{ Dependent variable: } & \multicolumn{2}{|c|}{ VAPC } & \multicolumn{2}{|c|}{ TFP } \\
\hline & DiD & FE DiD & DiD & FE DiD \\
\hline Interaction & $\begin{array}{c}-0.145^{* * *} \\
(0.008)\end{array}$ & $\begin{array}{c}0.002 \\
(0.006)\end{array}$ & $\begin{array}{c}-0.120^{* * *} \\
(0.006)\end{array}$ & $\begin{array}{c}-0.018^{* * *} \\
(0.005)\end{array}$ \\
\hline \multicolumn{5}{|l|}{ Workforce characteristics } \\
\hline Median age & $\begin{array}{c}0.016^{* * *} \\
(0.000)\end{array}$ & $\begin{array}{c}0.007^{* * *} \\
(0.000)\end{array}$ & $\begin{array}{c}0.012^{* * *} \\
(0.000)\end{array}$ & $\begin{array}{c}0.009^{* * *} \\
(0.000)\end{array}$ \\
\hline Share of females & $\begin{array}{c}-0.385^{* * *} \\
(0.006)\end{array}$ & $\begin{array}{c}-0.084^{* * *} \\
(0.015)\end{array}$ & $\begin{array}{c}-0.166^{* * *} \\
(0.006)\end{array}$ & $\begin{array}{l}-0.023 \\
(0.014)\end{array}$ \\
\hline Share of college graduates & $\begin{array}{c}0.381^{* * *} \\
(0.010)\end{array}$ & $\begin{array}{l}-0.009 \\
(0.018)\end{array}$ & $\begin{array}{c}0.325^{* * *} \\
(0.010)\end{array}$ & $\begin{array}{c}0.079^{* * *} \\
(0.017)\end{array}$ \\
\hline Share of vocational graduates & $\begin{array}{c}0.968^{* * *} \\
(0.043)\end{array}$ & $\begin{array}{c}0.016 \\
(0.076)\end{array}$ & $\begin{array}{c}0.886^{* * *} \\
(0.041)\end{array}$ & $\begin{array}{c}0.342^{* * *} \\
(0.074)\end{array}$ \\
\hline Share of primary school graduates & $\begin{array}{c}0.057^{* * *} \\
(0.011)\end{array}$ & $\begin{array}{c}-0.040^{* *} \\
(0.018)\end{array}$ & $\begin{array}{c}0.063^{* * *} \\
(0.011)\end{array}$ & $\begin{array}{c}0.002 \\
(0.017)\end{array}$ \\
\hline Share of managers & $\begin{array}{c}0.286^{* * *} \\
(0.014)\end{array}$ & $\begin{array}{c}0.016 \\
(0.022)\end{array}$ & $\begin{array}{c}0.407^{* * *} \\
(0.014)\end{array}$ & $\begin{array}{c}0.102^{* * * *} \\
(0.024)\end{array}$ \\
\hline Share of blue collar workers & $\begin{array}{c}0.323^{* * *} \\
(0.008)\end{array}$ & $\begin{array}{c}0.217^{* * *} \\
(0.012)\end{array}$ & $\begin{array}{c}0.221^{* * *} \\
(0.007)\end{array}$ & $\begin{array}{c}-0.025^{* *} \\
(0.011)\end{array}$ \\
\hline Treated region & $\begin{array}{c}-0.057^{* * *} \\
(0.006)\end{array}$ & & $\begin{array}{c}-0.010^{* *} \\
(0.005)\end{array}$ & \\
\hline \multicolumn{5}{|l|}{ Year } \\
\hline 2005 & $\begin{array}{c}0.055^{* * *} \\
(0.006)\end{array}$ & $\begin{array}{c}0.015^{* * *} \\
(0.004)\end{array}$ & $\begin{array}{c}0.026^{* * *} \\
(0.005)\end{array}$ & $\begin{array}{c}0.044^{* * *} \\
(0.003)\end{array}$ \\
\hline 2006 & $\begin{array}{c}0.121^{* * *} \\
(0.007)\end{array}$ & $\begin{array}{c}0.044^{* * *} \\
(0.005)\end{array}$ & $\begin{array}{c}0.064^{* * *} \\
(0.006)\end{array}$ & $\begin{array}{c}0.062^{* * * *} \\
(0.004)\end{array}$ \\
\hline 2007 & $\begin{array}{c}0.205^{* * *} \\
(0.007)\end{array}$ & $\begin{array}{c}0.184^{* * *} \\
(0.005)\end{array}$ & $\begin{array}{c}0.049 * * * \\
(0.006)\end{array}$ & $\begin{array}{c}0.142^{* * *} \\
(0.004)\end{array}$ \\
\hline \multicolumn{5}{|l|}{ Industry } \\
\hline Extraction & $\begin{array}{c}0.550^{* * *} \\
(0.144)\end{array}$ & & $\begin{array}{c}0.452^{* * *} \\
(0.139)\end{array}$ & \\
\hline Production & $\begin{array}{c}0.020 \\
(0.134)\end{array}$ & & $\begin{array}{c}0.348^{* * *} \\
(0.132)\end{array}$ & \\
\hline Construction & $\begin{array}{l}-0.125 \\
(0.134)\end{array}$ & & $\begin{array}{c}0.351^{* * *} \\
(0.132)\end{array}$ & \\
\hline Hotels and restaurants & $\begin{array}{c}-0.544^{* * * *} \\
(0.134)\end{array}$ & & $\begin{array}{c}0.001 \\
(0.132)\end{array}$ & \\
\hline Transport & $\begin{array}{c}0.043 \\
(0.135)\end{array}$ & & $\begin{array}{c}0.454^{* * *} \\
(0.132)\end{array}$ & \\
\hline Real estate & $\begin{array}{c}0.122 \\
(0.134)\end{array}$ & & $\begin{array}{c}0.596^{* * *} \\
(0.132)\end{array}$ & \\
\hline Education & $\begin{array}{c}-0.653^{*} \\
(0.347)\end{array}$ & & $\begin{array}{c}0.938^{* * *} \\
(0.358)\end{array}$ & \\
\hline Intercept & $\begin{array}{c}4.571^{* * *} \\
(0.135)\end{array}$ & $\begin{array}{c}5.002^{* * *} \\
(0.021)\end{array}$ & $\begin{array}{c}3.290^{* * *} \\
(0.132)\end{array}$ & $\begin{array}{c}3.839^{* * *} \\
(0.019)\end{array}$ \\
\hline
\end{tabular}

Note: Standard errors in parentheses; variables excluded due to colinearity: Share of white collar workers, Share of high school graduates, year 2004, Industry 1 (Agriculture and fishing). We control for 13 different industries, but report only significant coefficients. Threshold value for the assignation to the treatment group: $33 \%$ 
Table 8: The effect of ALMPs experiment on firm-level performance outcomes with control for the share of new hires coming from unemployment - DiD analysis

\begin{tabular}{|c|c|c|c|c|}
\hline \multirow[t]{2}{*}{ Dependent variable: } & \multicolumn{2}{|c|}{ VAPC } & \multicolumn{2}{|c|}{$\overline{\mathrm{TFP}}$} \\
\hline & DiD & FE DiD & DiD & FE DiD \\
\hline Interaction (33\% threshold) & $\begin{array}{c}-0.160^{* * *} \\
(0.008)\end{array}$ & $\begin{array}{c}0.007 \\
(0.006)\end{array}$ & $\begin{array}{c}-0.122^{* * *} \\
(0.007)\end{array}$ & $\begin{array}{l}-0.009^{*} \\
(0.005)\end{array}$ \\
\hline $\begin{array}{l}\text { Share of previously } \\
\text { unemployed in new hires }\end{array}$ & $\begin{array}{c}-0.132^{* * *} \\
(0.015)\end{array}$ & $\begin{array}{l}-0.002 \\
(0.014)\end{array}$ & $\begin{array}{c}-0.057^{* * *} \\
(0.014)\end{array}$ & $\begin{array}{c}-0.061^{* * *} \\
(0.013)\end{array}$ \\
\hline \multicolumn{5}{|l|}{ Workforce characteristics } \\
\hline Median age & $\begin{array}{c}0.016^{* * *} \\
(0.000)\end{array}$ & $\begin{array}{c}0.005^{* * *} \\
(0.000)\end{array}$ & $\begin{array}{c}0.012^{* * *} \\
(0.000)\end{array}$ & $\begin{array}{c}0.008^{* * * *} \\
(0.000)\end{array}$ \\
\hline Share of females & $\begin{array}{c}-0.369^{* * *} \\
(0.007)\end{array}$ & $\begin{array}{c}0.011 \\
(0.016)\end{array}$ & $\begin{array}{c}-0.151^{* * *} \\
(0.007)\end{array}$ & $\begin{array}{c}0.017 \\
(0.017)\end{array}$ \\
\hline Share of college graduates & $\begin{array}{c}0.393^{* * *} \\
(0.011)\end{array}$ & $\begin{array}{c}-0.053^{* * *} \\
(0.019)\end{array}$ & $\begin{array}{c}0.368^{* * *} \\
(0.012)\end{array}$ & $\begin{array}{c}0.043^{* *} \\
(0.019)\end{array}$ \\
\hline Share of vocational graduates & $\begin{array}{c}1.091^{* * *} \\
(0.049)\end{array}$ & $\begin{array}{c}0.011 \\
(0.085)\end{array}$ & $\begin{array}{c}1.084^{* * *} \\
(0.050)\end{array}$ & $\begin{array}{c}0.267^{* * *} \\
(0.087)\end{array}$ \\
\hline Share of primary school graduates & $\begin{array}{c}0.045^{* * *} \\
(0.013)\end{array}$ & $\begin{array}{c}-0.044^{* *} \\
(0.019)\end{array}$ & $\begin{array}{c}0.064^{* * *} \\
(0.013)\end{array}$ & $\begin{array}{l}-0.009 \\
(0.019)\end{array}$ \\
\hline Share of managers & $\begin{array}{c}0.349^{* * *} \\
(0.017)\end{array}$ & $\begin{array}{c}0.110^{* * *} \\
(0.028)\end{array}$ & $\begin{array}{c}0.584^{* * *} \\
(0.019)\end{array}$ & $\begin{array}{c}0.100^{* * *} \\
(0.032)\end{array}$ \\
\hline Share of blue collar workers & $\begin{array}{c}0.412^{* * *} \\
(0.009)\end{array}$ & $\begin{array}{c}0.232^{* * *} \\
(0.013)\end{array}$ & $\begin{array}{c}0.277^{* * *} \\
(0.009)\end{array}$ & $\begin{array}{c}-0.057^{* * *} \\
(0.013)\end{array}$ \\
\hline Treated region & $\begin{array}{c}-0.060^{* * *} \\
(0.006)\end{array}$ & & $\begin{array}{c}-0.009^{*} \\
(0.005)\end{array}$ & \\
\hline \multicolumn{5}{|l|}{ Year } \\
\hline 2005 & $\begin{array}{c}0.051^{* * *} \\
(0.006)\end{array}$ & $\begin{array}{c}0.015^{* * *} \\
(0.004)\end{array}$ & $\begin{array}{c}0.024^{* * *} \\
(0.005)\end{array}$ & $\begin{array}{c}0.047^{* * *} \\
(0.004)\end{array}$ \\
\hline 2006 & $\begin{array}{c}0.131^{* * *} \\
(0.008)\end{array}$ & $\begin{array}{c}0.050^{* * *} \\
(0.005)\end{array}$ & $\begin{array}{c}0.066^{* * *} \\
(0.006)\end{array}$ & $\begin{array}{c}0.066^{* * *} \\
(0.004)\end{array}$ \\
\hline 2007 & $\begin{array}{c}0.214^{* * *} \\
(0.008)\end{array}$ & $\begin{array}{c}0.182^{* * *} \\
(0.005)\end{array}$ & $\begin{array}{c}0.047^{* * *} \\
(0.006)\end{array}$ & $\begin{array}{c}0.150^{* * *} \\
(0.005)\end{array}$ \\
\hline \multicolumn{5}{|l|}{ Industry } \\
\hline Extraction & $\begin{array}{c}0.565^{* * *} \\
(0.140)\end{array}$ & & $\begin{array}{c}0.459^{* * *} \\
(0.139)\end{array}$ & \\
\hline Production & $\begin{array}{c}0.016 \\
(0.130)\end{array}$ & & $\begin{array}{c}0.330^{* *} \\
(0.131)\end{array}$ & \\
\hline Construction & $\begin{array}{l}-0.150 \\
(0.130)\end{array}$ & & $\begin{array}{c}0.326^{* *} \\
(0.131)\end{array}$ & \\
\hline Hotels and restaurants & $\begin{array}{c}-0.535^{* * *} \\
(0.130)\end{array}$ & & $\begin{array}{c}0.000 \\
(0.131)\end{array}$ & \\
\hline Transport & $\begin{array}{c}0.025 \\
(0.130)\end{array}$ & & $\begin{array}{c}0.421^{* * *} \\
(0.131)\end{array}$ & \\
\hline Real estate & $\begin{array}{c}0.061 \\
(0.130)\end{array}$ & & $\begin{array}{c}0.540^{* * *} \\
(0.131)\end{array}$ & \\
\hline Education & $\begin{array}{c}-0.618^{*} \\
(0.338)\end{array}$ & & $\begin{array}{c}0.930^{* * *} \\
(0.347)\end{array}$ & \\
\hline Intercept & $\begin{array}{c}4.545^{* * *} \\
(0.130)\end{array}$ & $\begin{array}{c}5.004^{* * *} \\
(0.021)\end{array}$ & $\begin{array}{c}3.239^{* * *} \\
(0.132)\end{array}$ & $\begin{array}{c}3.847^{* * *} \\
(0.021)\end{array}$ \\
\hline
\end{tabular}

$* \mathrm{p}<0.1, * * \mathrm{p}<0.05, * * * \mathrm{p}<0.01$

Note: Standard errors in parentheses; variable excluded due to colinearity: Share of white collar workers, Share of high school graduates, year 2004, Industry 1 (Agriculture and fishing). We control for 13 different industries, but report only significant coefficients. Threshold value for the assignation to the treatment group: $33 \%$ 
Table 9: Sensitivity analysis - firm-level performance outcomes

\begin{tabular}{|c|c|c|}
\hline & $\overline{\mathrm{DiD}}$ & FE DiD \\
\hline \multicolumn{3}{|l|}{ Baseline results } \\
\hline Workforce Turnover & $\begin{array}{c}0.079^{* * *} \\
(0.004)\end{array}$ & $\begin{array}{r}0.011^{* *} \\
(0.004)\end{array}$ \\
\hline $\begin{array}{l}\text { Share of previously unemployed } \\
\text { in new hires }\end{array}$ & $\begin{array}{c}0.007^{* * *} \\
(0.001)\end{array}$ & $\begin{array}{r}0.004^{* *} \\
(0.002)\end{array}$ \\
\hline \multicolumn{3}{|c|}{ Treatment firms defined with 50\% threshold } \\
\hline Workforce Turnover & $\begin{array}{c}0.078^{* * *} \\
(0.004)\end{array}$ & $\begin{array}{c}0.013^{* * *} \\
(0.004)\end{array}$ \\
\hline $\begin{array}{l}\text { Share of previously unemployed } \\
\text { in new hires }\end{array}$ & $\begin{array}{c}0.006^{* * *} \\
(0.001)\end{array}$ & $\begin{array}{c}0.004^{* *} \\
(0.002)\end{array}$ \\
\hline \multicolumn{3}{|c|}{ Control firms defined with $25 \%$ threshold } \\
\hline Workforce Turnover & $\begin{array}{c}0.078^{* * *} \\
(0.004)\end{array}$ & $\begin{array}{r}0.010^{* *} \\
(0.004)\end{array}$ \\
\hline Share of previously unemployed & $\begin{array}{c}0.007^{* * *} \\
(0.001)\end{array}$ & $\begin{array}{r}0.004^{* *} \\
(0.002)\end{array}$ \\
\hline
\end{tabular}

Note: Standard errors in parentheses. Controls included: year, hiring region, industry dummies and workforce characteristics.

Table 10: Sensitivity analysis - firm-level performance outcomes

\begin{tabular}{|c|c|c|}
\hline & $\mathrm{DiD}$ & FE DiD \\
\hline \multicolumn{3}{|l|}{ Baseline results } \\
\hline Value added per worker & $\begin{array}{c}-0.144^{* * *} \\
(0.008)\end{array}$ & $\begin{array}{c}0.002 \\
(0.006)\end{array}$ \\
\hline TFP & $\begin{array}{c}-0.120^{* * *} \\
(0.006)\end{array}$ & $\begin{array}{c}-0.018^{* * *} \\
(0.005)\end{array}$ \\
\hline \multicolumn{3}{|c|}{ Treatment firms defined with $50 \%$ threshold } \\
\hline Value added per worker & $\begin{array}{c}-0.183^{* * *} \\
(0.007)\end{array}$ & $\begin{array}{c}-0.003 \\
(0.006)\end{array}$ \\
\hline TFP & $\begin{array}{c}-0.135^{* * *} \\
(0.006)\end{array}$ & $\begin{array}{c}-0.020^{* * *} \\
(0.005)\end{array}$ \\
\hline \multicolumn{3}{|c|}{ Control firms defined with $25 \%$ threshold } \\
\hline Value added per worker & $\begin{array}{c}-0.144^{* * *} \\
(0.008)\end{array}$ & $\begin{array}{c}0.002 \\
(0.006)\end{array}$ \\
\hline $\mathrm{TFP}$ & $\begin{array}{c}-0.118^{* * *} \\
(0.006)\end{array}$ & $\begin{array}{c}-0.017^{* * * *} \\
(0.005)\end{array}$ \\
\hline
\end{tabular}

${ }^{*} \mathrm{p}<0.1,{ }^{* *} \mathrm{p}<0.05,{ }^{* * *} \mathrm{p}<0.01$

Note: Standard errors in parentheses. Controls included: year, hiring region, industry dummies and workforce characteristics. 
Table 11: Sensitivity analysis - Placebo tests - interaction term in the Placebo DiD estimations

\begin{tabular}{|c|c|c|}
\hline & DiD & FE DiD \\
\hline \multicolumn{3}{|c|}{ Dependent variable: Turnover } \\
\hline Interaction (placebo) & $\begin{array}{c}-0.024^{* * *} \\
(0.004)\end{array}$ & $\begin{array}{c}-0.002 \\
(0.005)\end{array}$ \\
\hline \multicolumn{3}{|l|}{ Dependent variable: SU } \\
\hline Interaction (placebo) & $\begin{array}{c}0.001 \\
(0.001)\end{array}$ & $\begin{array}{c}0.001 \\
(0.002)\end{array}$ \\
\hline \multicolumn{3}{|c|}{ Dependent variable: TFP } \\
\hline Interaction (placebo) & $\begin{array}{c}0.015^{* *} \\
(0.006)\end{array}$ & $\begin{array}{c}-0.010^{*} \\
(0.006)\end{array}$ \\
\hline
\end{tabular}

${ }^{*} \mathrm{p}<0.1,{ }^{* *} \mathrm{p}<0.05, * * * \mathrm{p}<0.01$

Note: Standard errors in parentheses. Controls included: year, hiring region, industry dummies and workforce characteristics. 